\title{
Karakteristik karies periode gigi campuran pada anak usia 6-7 Tahun di Kecamatan Tanjungsari Sumedang
}

\author{
Diani Prisinda ${ }^{1 *}$, Indah Suasani Wahyuni ${ }^{2}$, Prima Andisetyanto ${ }^{3}$, Yuliawati Zenab ${ }^{4}$ \\ ${ }^{1}$ Departemen Konservasi Gigi, Fakultas Kedokteran Gigi, Universitas Padjajaran, Indonesia \\ ${ }^{2}$ Departemen Ilmu Penyakit Mulut, Fakultas Kedokteran Gigi, Universitas Padjajaran, Indonesia \\ ${ }^{3}$ Departemen Ilmu Kedokteran Gigi Anak, Fakultas Kedokteran Gigi, Universitas Padjajaran, Indonesia \\ ${ }^{4}$ Departemen Ortodonti, Fakultas Kedokteran Gigi, Universitas Padjajaran, , Indonesia
}

*Korespondensi: diani.prisinda@fkg.unpad.ac.id

\begin{abstract}
ABSTRAK
Pendahuluan: Karies gigi merupakan salah satu masalah kesehatan gigi di Indonesia. Riset Kesehatan Dasar tahun 2013 menunjukkan status karies gigi masyarakat masih tinggi. Banyak orang beranggapan bahwa gigi sulung tidak perlu dirawat karena akan digantikan oleh gigi permanen sehingga kurang memperhatikan kesehatan gigi sulung anak, akibatnya keadaan gigi sulung yang dijumpai di praktek dokter gigi seringkali sudah mengalami kerusakan parah. Tujuan penelitian ini adalah mendapatkan data mengenai karakteristik karies periode gigi campuran pada anak usia 6-7 tahun, sebagai dasar penelitian karies gigi lebih lanjut. Metode: Jenis penelitian adalah deskriptif dengan pendekatan cross sectional. Populasi adalah anak usia 6-7 tahun dan siswa SD kelas 1 di Kecamatan Tanjungsari, Sumedang. Teknik purposive sampling mendapatkan subyek penelitian sejumlah 52 anak usia 6-7 tahun yang merupakan siswa kelas 1 dari salah satu SD. Instrumen penelitian yaitu: sinar lampu, kaca mulut, sonde, alat tulis dan formulir pemeriksaan. Data hasil pemeriksaan diolah menggunakan program Excel Office. Hasil: Permukaan gigi permanen yang paling banyak mengalami karies adalah oklusal, sedangkan pada gigi sulung adalah permukaan mesial. Kedalaman karies yang paling banyak ditemukan pada gigi permanen adalah superfisial, sedangkan pada gigi sulung adalah profunda. Ditemukan sejumlah 22 gigi permanen mengalami kerusakan, 343 gigi sulung mengalami kerusakan dan 108 gigi sulung hilang karena karies. Simpulan: Simpulan penelitian ini menunjukkan terdapat perbedaan karakteristik karies gigi permanen dan gigi sulung pada periode gigi campuran anak usia 6-7 tahun di Kecamatan Tanjungsari Sumedang.
\end{abstract}

Kata kunci: Karakteristik karies, periode gigi campuran, gigi permanen, gigi sulung.

\section{Caries characteristic of mixed dentition in children aged 6-7 years in Tanjungsari sub-district Sumedang.}

\begin{abstract}
Introduction: Dental caries is one of the dental health problems in Indonesia. Basic Health Research in 2013 showed that community dental caries status was still high. Many people assume that deciduous teeth do not need to be treated because they will be replaced by permanent teeth so that they pay less attention to the child's primary teeth, and the condition of the primary teeth found in dental practice often has suffered severe damage. The purpose of this study was to obtain the characteristics of caries in mixed dentition period in children aged 6-7 years. Method: The research method is descriptive with cross sectional approach. The population was children aged 6-7 years and grade 1 elementary school students in Tanjungsari sub-district, Sumedang. The purposive sampling technique obtained the research subjects as many as 52 children. The research instruments were: white light, dental miror, sonde, stationery and examination forms. The data was processed using the Excel Office program. Results: The most commonly found caries were on occlusal surfaces of permanent teeth, whereas those in the deciduous teeth were on mesial surfaces. The most commonly found caries depth in permanent teeth is superficial, whereas in primary teeth is profound. As many as 22 permanent teeth were found decay, 343 deciduous teeth were damaged and 108 deciduous teeth were missing or extracted due to caries. Conclusion: There are differences in the characteristics of permanent teeth and deciduous teeth caries in the mixed dentition of children aged 6-7 years in Tanjungsari sub-district, Sumedang.
\end{abstract}

Keywords: Caries characteristic, mixed dentition period, permanent teeth, deciduous teeth. 


\section{PENDAHULUAN}

Karies gigi merupakan salah satu masalah dalam bidang kesehatan gigi dan mulut yang banyak diderita masyarakat Indonesia. Berdasarkan laporan Riset Kesehatan Dasar (Riskesdas) ${ }^{1}$ tahun 2013 nilai indeks DMF-T di Indonesia diketahui sebesar 4.6, dengan nilai $\mathrm{D}-\mathrm{T}=1,6, \mathrm{M}-\mathrm{T}=1,9$, dan $\mathrm{F}-\mathrm{T}=0,08$. Nilai indeks DMF-T di Jawa Barat juga diketahui cukup tinggi yaitu 4,1. Nilai tersebut menunjukkan bahwa status karies gigi di Indonesia masih tinggi menurut kategori yang dikeluarkan oleh WHO. ${ }^{1-3}$

Tingkat keparahan karies menurut WHO berdasarkan indeks DMF-T dan atau def- $t$ dikategorikan menjadi sangat rendah $(0,0-1,1)$, rendah (1,2-2,6), Sedang (2,7-4,4), Tinggi (4,5$6,5)$ dan sangat tinggi $(>6,5){ }^{3}$ Nilai tersebut dapat dijadikan pedoman dalam menentukan strategi penanggulangan masalah kondisi karies yang parah pada masyarakat melalui program promotif dan pencegahan, sehingga diharapkan di masa yang akan datang dapat mengalami perbaikan. Upaya ini bagi anak sekolah membutuhkan kerjasama yang baik antara dokter gigi di Puskesmas sebagai penyedia jasa pelayanan kesehatan, dengan pihak sekolah melalui kegiatan UKS/UKGS. Orang tua selanjutnya juga berperan dalam mendukung upaya pemeliharaan kesehatan gigi dan mulut di rumah. ${ }^{1,2}$

Usia anak sekolah dasar terutama pada tingkatan kelas satu adalah kelompok usia yang mengalami masa geligi campuran yang sering menderita kelainan gigi dan mulut. Pada usia tersebut memiliki kemungkinan asupan nutrisi dapat menjadi tidak seimbang akibat adanya masalah kesehatan gigi dan mulut, oleh karena itu pada usia ini kesehatan gigi dan mulut harus lebih diperhatikan karena dapat mempengaruhi konsentrasi belajar dan prestasi siswa di sekolah. ${ }^{2}$ Usia 6-7 tahun merupakan kategori usia yang dijadikan dasar pengalaman karies dan sebagai acuan untuk melihat pengalaman karies pada gigi sulung. ${ }^{3}$ Pada usia ini gigi permanen mulai erupsi dan membutuhkan perhatian agar tidak terjadi kerusakan dini, yang berpotensi mengganggu kualitas hidup seseorang di masa yang akan datang.

Anak dengan usia 6-7 tahun biasanya belum mampu melaksanakan upaya pemeliharaan kesehatan diri sendiri secara mandiri. Tingkat pengetahuan dan kesadaran anak pada usia ini untuk memelihara kesehatan giginya sendiri juga belum kuat, selain itu asupan makanan masih sangat dipengaruhi oleh keluarga dan lingkungan sekolah. Keluarga atau lingkungan sekolah yang membiarkan banyak asupan makanan yang bersifat kariogenik dan tidak memperhatikan asupan makanan bergizi menjadi salah satu faktor resiko mendukung terjadinya karies gigi, sehingga usia anak sekolah merupakan usia yang tepat untuk diberikan intervensi secara dini dalam hal upaya pemeliharaan kesehatan, dan pencegahan penyakit gigi dan mulut.,4 Data penelitian sebelumnya mengenai karakteristik karies sebagian besar dari sudut pandang penilaian indeks atau status karies, sedangkan penelitian mengenai permukaan gigi dan kedalaman karies yang paling banyak ditemukan belum banyak ditampilkan terutama pada periode gigi campuran. Tujuan penelitian ini adalah untuk mendapatkan data karakteristik karies meliputi permukaan yang paling banyak terkena karies serta kedalaman karies baik gigi permanen maupun gigi sulung pada periode campuran anak usia 6-7 tahun.

\section{METODE}

Jenis penelitian deskriptif dangan teknik pengambilan data crosssectional. Pemeriksaan dilakukan pada seluruh siswa kelas 1 SD yang bersedia mendapatkan pemeriksaan kesehatan gigi dan mulutsebagai subyek penelitian. Guru bertindak selaku wali murid yang menandatangani lembar persetujuan pemeriksaan (informed consent) sebelum pemeriksaan klinis dilakukan dan jika tidak bersedia maka tidak diikutsertakan dalam penelitian. Pemeriksa dan pencatat data penelitian adalah 2 orang dokter gigi yang sebelumnya telah memiliki pengetahuan dan mendapatkan pelatihan kalibrasi untuk melakukan pemeriksaan gigi dan mulut, terutama karies gigi.

Pemeriksaan gigi dan mulut dilakukan secara visual dengan bantuan alat pemeriksaan berupa kaca mulut dan sonde serta menggunakan bantuan cahaya lampu putih. Data yang diperoleh dicatat dalam formulir pemeriksaan/odontogram, selanjutnya diolah secara statistik menggunakan program Excel Office dan dideskripsikan melalui tabel distribusi frekwensi.

Populasi penelitian adalah anak usia 6-7 tahun dan merupakan siswa kelas 1 SD di Kecamatan Tanjungsari, Sumedang, Jawa Barat, Indonesia. Teknik sampling yang digunakan adalah purposive sampling, sehingga didapatkan sejumlah 52 anak sebagai subyek penelitian yang memenuhi kriteria inklusi, 
di antaranya adalah sehat jasmani rohani serta tidak memiliki keterbatasan fisik maupun mental yang dapat menghambat jalannya penelitian.

Data identitas pasien meliputi: nama/inisial, usia pasien, jenis kelamin, lokasi terjadinya karies (mesial, distal, oklusal, bukal/labial), kedalaman karies (superfisial, media, profunda), ada atau tidaknya plak dari masing-masing individu, serta pencatatan data kesehatan gigi yang meliputi jumlah gigi yang mengalami karies, kehilangan gigi prematur dan gigi yang sudah ditambal, baik pada gigi sulung dan gigi permanen yang sudah erupsi. Data ditampilkan dalam bentuk tabel-tabel. Rekomendasi etik penelitian kesehatan diberikan oleh Komite Etik Penelitian Kesehatan Fakultas Kedokteran, Universitas Padjadjaran (KEPK FK Unpad), No: 833/ UN6.C1.3.2/KEPK/PN/2016.

\section{HASIL}

Total jumlah siswa yang diperiksa berjumlah 52 siswa, terdiri dari 34 laki-laki dan 18 perempuan dengan rentang usia 6 sampai dengan 7 tahun. Hasil pemeriksaan menunjukkan bahwa permukaan gigi permanen yang paling sering terkena karies adalah pada bagian oklusal, sedangkan pada gigi sulung pada permukaan proksimal yaitu mesial diikuti oleh distal (Tabel 1). Kedalaman karies yang paling banyak ditemukan pada gigi sulung adalah karies profunda sebanyak 149 gigi, diikuti oleh kedalaman media sebanyak 110 gigi dan kedalaman superfisial sebanyak 71 gigi. Kedalaman karies pada gigi permanen menunjukkan hasil yang berbeda, yaitu lebih banyak ditemukan yang masih superfisialis sebanyak 14 gigi, sebanyak 8 kedalaman media dan tidak ditemukan karies profunda. Hasil tersebut seperti tampak pada tabel 2 , serta gambaran klinis kedalaman karies superfisial, media dan profunda (Gambar 1).

Hasil pemeriksaan seluruh gigi tidak ditemukan satupun gigi yang terdapat tambalan, serta hampir seluruh subjek penelitian terdapat plak di permukaan giginya dan dari seluruh siswa yang diperiksa hanya terdapat 3 siswa saja yang bebas karies (Gambar 2 menunjukkan kondisi free caries), sehingga prevalensi karies gigi pada kelompok subyek penelitian ini adalah sebesar 94,23\% ((52-3)/52 x 100\%). Selanjutnya tabel 3 memperlihatkan data mengenai jumlah gigi yang mengalami kerusakan gigi (decay), kehilangan gigi (missing) dan tambalan (filling). Berdasarkan tabel tersebut indikator kesehatan gigi sulung menunjukan indeks def- $\mathrm{t}=8,67$ (451/52) dan indikator kesehatan gigi permanen menunjukan indeks DMF-T=0,423(22/52).

Tabel 1. Data permukaan gigi yang mengalami karies

\begin{tabular}{lcccccc}
\hline & $\begin{array}{c}\text { Tidak ada } \\
\text { Karies }\end{array}$ & Oklusal & Mesial & Distal & Labial & Lingual \\
\hline Gigi Permanen & 42 & 21 & 1 & 1 & 1 & 2 \\
Gigi Sulung & 4 & 76 & 152 & 129 & 50 & 26 \\
\hline
\end{tabular}

Tabel 2. Data kedalaman karies gigi

\begin{tabular}{ccccc}
\hline & Superfisial & Media & Profunda & Total \\
\hline Gigi Permanen & 14 & 8 & 0 & 22 \\
Gigi Sulung & 71 & 110 & 149 & 330 \\
\hline
\end{tabular}
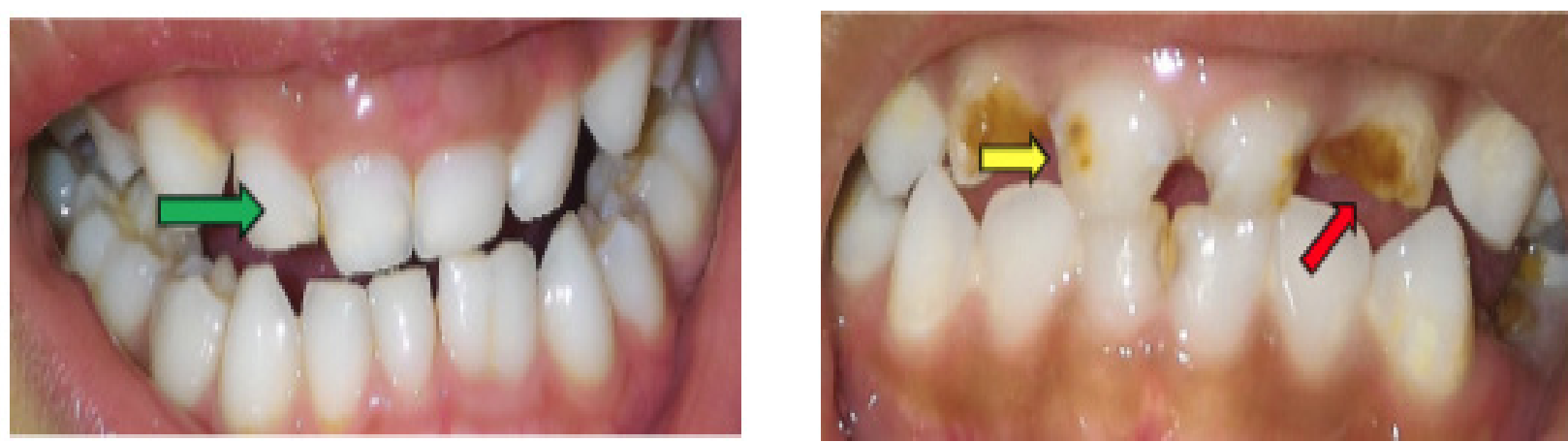

Gambar 1. Hasil pemeriksaan karies superfisial (ditunjukkan oleh gambar kiri/panah hijau/gigi 51, 52), karies media (ditunjukkan oleh gambar kanan/panah kuning/gigi 51), dan karies profunda (ditunjukkan oleh gambar kanan/panah merah/ gigi 62), pada subjek penelitian 


\begin{tabular}{cccccc}
\hline \multicolumn{7}{c}{ Tabel 3. Data kerusakan gigi, kehilangan gigi dan tambalan } \\
\hline & Kerusakan gigi & Kehilangan gigi & Tambalan gigi & Total & Indeks Karies \\
\hline Gigi Permanen & 22 & 0 & 0 & 22 & DMF-T $=0,423$ \\
Gigi Sulung & 343 & 108 & 0 & 451 & Def- $\mathrm{t}=8,67$ \\
\hline
\end{tabular}

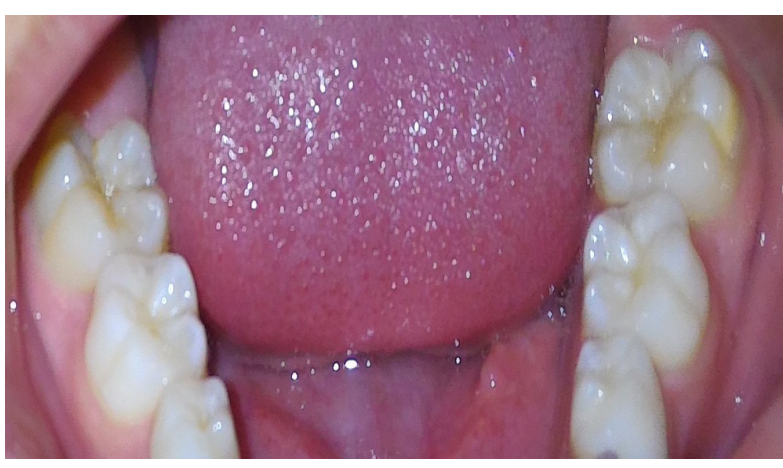

Gambar 2. Hasil pemeriksaan free caries pada gigi molar pertama tetap subjek penelitian

\section{PEMBAHASAN}

Penyakit yang saat ini memiliki tingkat prevalensi tertinggi pada anak usia sekolah di Indonesia adalah penyakit gigi dan mulut $74,4 \%$, penyakit cacingan $60-80 \%$, penyakit pernapasan dan diare $30 \%$. Hasil penelitian menunjukkan hampir seluruh anak mengalami karies gigi yang tidak dirawat, dengan tidak adanya gigi yang sudah ditambal. Hal ini dapat menyebabkan gangguan kesehatan anak, seperti rendahnya indeks massa tubuh anak, anemia, kurang tidur dan berujung pada menurunnya kualitas hidup anak tersebut. ${ }^{3}$

Menurut Black dalam Hiremath ${ }^{4}$, karies merupakan suatu pelarutan mineral kalsium oleh asam laktat yang diikuti oleh terdekomposisinya matriks organik pada email dan dentin. Pelarutan ini akan menyebabkan timbulnya suatu kavitas yang dimulai dari permukaan gigi. Karies gigi adalah infeksi mikroorganisme pada gigi yang menyebabkan terjadinya proses pelarutan dan penghancuran jaringan keras gigi. Lesi karies hanya dapat terjadi jika masa bakteri yang memproduksi asam dan menciptakan lingkungan asam di sekitar gigi sehingga menyebabkan demineralisasi gigi. Karies gigi juga merupakan infeksi pada gigi yang menghancurkan jaringan keras (email, dentin dan sementum) sehingga terbentuk kavitas. Lesi hanya terjadi jika ada lingkungan yang mendukung pada rongga mulut. Bakteri kariogenik seperti Streptococcus mutans, makanan, kebersihan mulut dan waktu terjadinya merupakan hal yang penting pada proses terjadinya karies. ${ }^{4}$
Faktor resiko karies dapat dibagi menjadi 2 kategori yaitu, faktor primer dan faktor modifikasi. Faktor primer adalah faktor biologis yang secara langsung memengaruhi biofilm, seperti saliva, efek buffer, komposisi saliva, jumlah, konsistensi, efek cleansing, diet, bentuk anatomi gigi, frekuensi serta jumlah makanan dan asupan fluoride. Faktor modifikasi yaitu faktor-faktor yang secara tidak langsung mempengaruhi biofilm, seperti status sosio ekonomi, lifestyle, riwayat dental dan riwayat medis. Faktor-faktor tersebut berpengaruh terhadap kualitas biofilm serta terjadinya karies. ${ }^{5}$

Hasil penelitian ini seperti tercantum pada tabel 1 menunjukkan bahwa anatomi gigi mempengaruhi ketahanan gigi terhadap karies. Permukaan oklusal merupakan bagian yang paling banyak mengalami karies gigi dibandingkan dengan permukaan lainnya pada gigi permanen, hal ini menunjukkan bahwa permukaan oklusal gigi permanen merupakan permukaan dengan resiko tinggi terkena karies pada usia 6-7 tahun. Permukaan gigi yang lain tampak belum banyak menunjukkan kerusakan, kemungkinan karena gigi permanen pada usia ini juga masih baru saja erupsi, kurang dari 2 tahun. Hal-hal yang dapat diupayakan untuk mencegah karies bertambah parah pada usia ini adalah dengan melakukan tindakan pencegahan primer specific protection berupa aplikasi topikal fluor dan atau pit and fissure sealant pada gigi permanen muda yang dapat dilakukan oleh tenaga profesional kesehatan gigi..$^{5-10}$

Berbeda dengan gigi permanen, maka pada gigi sulung karies paling banyak ditemukan pada permukaan mesial, diikuti oleh permukaan distal, atau dengan kata lain permukaan proksimal lebih banyak mengalami kerusakan dibandingkan dengan permukaan oklusal pada gigi sulung. Hal ini berhubungan dengan faktor diet dan kebersihan mulut. Anak usia 6-7 tahun cenderung lebih banyak mengkonsumsi makanan yang kariogenik dan bersifat lengket, makanan menempel terutama pada sela-sela gigi, namun tidak dibersihkan setiap hari dengan baik. Anak usia ini cenderung belum dapat melakukan pemeliharaan kebersihan mulut secara baik dan teratur, sehingga sisa makanan 
yang terperangkap pada sela-sela gigi mengalami dekomposisi dan menurunkan $\mathrm{pH}$ di sekitar gigi tersebut sehingga lambat laun akan mengakibatkan demineralisasi enamel gigi yang dapat membentuk kavitas. Selain itu gigi sulung pada masa ini sudah erupsi lebih lama dibandingkan gigi permanen, sehingga kerusakan yang dialami cenderung lebih parah. $^{4-6}$

Hasil penelitian pada tabel 2 menunjukkan tingkat kedalaman karies yang banyak ditemukan pada gigi permanen adalah kedalaman superfisial, diikuti media dan tidak ditemukan kedalaman profunda. Secara anatomi, email gigi permanen lebih tebal dibandingkan dengan ketebalan email gigi sulung, sehingga lebih tahan terhadap serangan karies. $^{4-5}$ Hal ini juga menjadi alasan bahwa pada penelitian ini pola kedalaman karies gigi sulung berkebalikan dibandingkan dengan gigi permanen. Pada gigi sulung lebih banyak ditemukan memiliki karies profunda, diikuti media dan superfisial. Karakteristik karies selain permukaan dan kedalaman karies adalah status karies yang dapat diukur menggunakan indikator/indeks karies. Indikator karies yang sering digunakan adalah indeks DMF-T untuk gigi permanen, yang merupakan penjumlahan dari indeks D-T, M-T, dan F-T dan menunjukkan banyaknya kerusakan gigi yang pernah dialami seseorang. Decay (D-T) merupakan jumlah gigi permanen yang mengalami karies atau gigi berlubang yang belum diobati atau ditambal, missing (M-T) merupakan jumlah gigi permanen yang dicabut atau masih berupa sisa akar yang mengalami kerusakan karena karies, serta filling (F-T) adalah jumlah gigi permanen yang telah dilakukan penumpatan atau ditambal. Indeks ini hanya berdasarkan pada 28 gigi, tidak termasuk molar ketiga, gigi yang belum erupsi, gigi hilang secara kongenital dan supernumerary, gigi yang hilang dengan alasan selain karies dan gigi yang direstorasi dengan alasan selain karies. Aturan dan prinsip perhitungannya adalah hanya pada gigi yang sudah erupsi, tidak ada gigi yang nilainya lebih dari 1, gigi yang hilang bukan karena karies tidak dimasukan kategori (M) dan pada gigi yang sama yang memiliki lebih dari satu tambalan tetap dihitung satu. ${ }^{4,5}$

Hasil penelitian ini menunjukan indeks DMF-T $=0,432$ berarti rata-rata dalam setiap mulut anak hampir tidak terdapat karies untuk gigi permanennya. Tingkat keparahan karies gigi permanen menurut WHO berdasarkan indeks DMF-T pada penelitian ini dikategorikan menjadi sangat rendah $(0,0-1,1)$. Hal ini sejalan dengan penelitian Amirabadi dkk bahwa rata-rata skor DMF-T pada umur 8 sampai 12 tahun, termasuk kategori sangat rendah menurut WHO. Penelitian tersebut juga menyatakan bahwa tidak terdapat hubungan antara waktu menyikat gigi dengan indeks DMF-T pada subyek penelitiannya. ${ }^{6}$

Indikator kesehatan gigi yang sering digunakan selanjutnya adalah Indeks def-t untuk gigi sulung. Komponennya terdiri dari gigi dengan karies yang tidak direstorasi (d), gigi yang diekstraksi atau hilang premature karena karies (e), dan gigi yang telah ditambal (f). Gigi sulung yang dicatat adalah yang hanya terdapat pada rongga mulut saat pemeriksaan, karena sulit menentukan apakah gigi yang telah dicabut (missing/e) adalah telah tanggal atau dicabut karena karies atau karena serial ekstraksi. ${ }^{4}$ Pada penelitian ini subjek penelitian adalah anak usia 6-7 tahun dan merupakan siswa kelas 1 SD, yang pada usia ini masih merupakan masa periode geligi campuran sehingga cara penghitungannya dihitung secara terpisah. Karies pada gigi permanen dihitung berdasarkan indeks DMT-T sedangkan pada gigi sulung dihitung berdasarkan indeks def-t. ${ }^{4}$ Hasil penelitian menunjukan indeks def- $t=8,67$ yang berarti rata-rata dalam setiap mulut anak terdapat kerusakan berupa karies dan atau diindikasikan untuk ekstraksi sejumlah 8 gigi sulung. Hal ini berarti tingkat keparahan karies menurut WHO berdasarkan indeks def-t dikategorikan sangat tinggi $(>6,5)$.

Penelitian Cypriano, dkk mengenai hal serupa namun dilakukan pada tiga daerah yang berdekatan, tingkat prevalensi karies juga termasuk tinggi dan penelitian ini menggunakan indeks lain selain DMF-T, dengan hasil ini diharapkan dapat menjadi acuan untuk meningkatkan kesehatan rongga mulut selama klinisi merencanakan rencana perawatan dan sebelum melakukan perawatan. ${ }^{7}$ Hasil penelitian ini juga sejalan dengan Aida dkk (2015) ${ }^{9}$, yang menunjukkan indeks def-t siswa PAUD Kelurahan Jati Kota Padang sebesar 5,18 yang menunjukan kategori tinggi, namun sedikit berbeda dibandingkan dengan hasil penelitian yang dilakukan Fathiah $(2015)^{8}$, yang menyatakan angka rerata kerusakan gigi permanen (def-t) pada SD Binaan Pelayanan Asuhan Jurusan Keperawatan Gigi Poltekkes Kemenkes Pontianak adalah 3,5 dan termasuk dalam kategori sedang. Hal ini kemungkinan disebabkan karena SD ini sudah dibina oleh Poltekkes sehingga indeks def- $t$ akan berangsur menurun. ${ }^{8}$ Sekolah dasar (SD) yang 
menjadi lokasi penelitian ini adalah SD di Kecamatan Tanjungsari Sumedang yang jarang mendapatkan penyuluhan tentang kesehatan gigi dan mulut.

Siswa yang terdapat di SD tersebut jarang melakukan kunjungan berkala ke dokter gigi secara pribadi sehingga diduga berhubungan dengan indeks def-t yang sangat tinggi. Hasil penelitian ini selain menunjukan prevalensi karies gigi pada gigi sulung lebih besar dibandingkan dengan prevalensi karies pada gigi permanen, juga ditemukan bahwa dari seluruh siswa yang diperiksa hanya terdapat 3 siswa saja yang bebas karies, sehingga prevalensi karies gigi pada kelompok subyek penelitian ini adalah sebesar 94,23\% ((52-3)/52 x 100\%; $\mathrm{n}=52)$.

Hal ini sejalan dengan penelitian yang dilakukan oleh Bhagat dan Shresta (2014) ${ }^{10}$, yang mendapatkan prevalensi karies pada anak sekolah di Nepal juga tinggi. WHO menyebutkan bahwa pada $32 \%$ anak berusia 12 tahun, atau pada usia akhir periode gigi campuran, ditemukan 3 atau lebih gigi yang berlubang, sedangkan pada anak-anak dan orang dewasa terdapat karies gigi antara $60-90 \%{ }^{8}$ Hasil pemeriksaan intra oral menunjukkan hampir terdapat plak pada seluruh subjek penelitian. Plak merupakan suatu lapisan semi transparan polisakarida dan beradhesi secara kuat dengan permukaan gigi serta terdiri dari organisme pathogen yang dapat mempengaruhi lingkungan rongga mulut. Suatu plak yang tipis dapat melekat pada pit dan fisur, permukaan halus mahkota gigi, daerah proksimal, serta pada restorasi yang overdentured.

Plak dapat terbentuk setiap hari ketika sedang makan. Beberapa bakteri dapat berkolonisasi di permukaan gigi dan membentuk plak secara berkesinambungan. Plak gigi yang menumpuk mengandung berbagai macam bakteri. Hal tersebut disebabkan semakin lama penumpukan plak terjadi maka komposisi bakteri plak gigi semakin beragam, seperti adanya bakteri Gram negatif yang melekat pada bakteri gram positif yang telah lebih dahulu melekat pada permukaan gigi.

Bakteri-bakteri tersebut mampu untuk melakukan perusakan pada jaringan keras gigi, jaringan gusi dan periodontal melalui zat-zat yang dikandung serta dihasilkan dalam proses metabolismenya yang berupa eksotoksin, endotoksin dan asam khususnya asam laktat. ${ }^{5}$ Penelitian ini juga menemukan informasi bahwa subyek penelitian yang diperiksa sebagian besar senang mengkonsumsi makanan manis terutama permen dan coklat bahkan dikonsumsi hampir setiap hari.

Menurut penelitian Ahmadzadeh, dkk ${ }^{11}$, bahwa konsumsi gula, waktu menyikat gigi dan usia pasien merupakan faktor penting yang sangat berhubungan dengan karies gigi, sehingga strategi yang efektif dan berkesinambungan diperlukan untuk upaya mengurangi konsumsi gula oleh anakanak. ${ }^{11}$ Dari hasil penelitian ini diperlukan intervensi berupa program promosi dan pencegahan karies untuk mempertahankan gigi permanen muda dan hal ini tepat jika dimulai di usia 6 - 7 tahun, karena karakteristik karies gigi permanen yang ditemukan adalah jumlah gigi yang mengalami karies masih sedikit, serta kedalaman karies masih banyak yang superfisialis. Intervensi dapat berupa pemberian topical fluor, fissure sealant, serta penambalan permanen.

Pencegahan terhadap akumulasi berlebihan dan retensi plak juga perlu dilakukan karena plak merupakan awal mula terjadinya karies. ${ }^{4,5}$ Sejalan dengan penelitian yang dilakukan Qurati Ayun, dkk, (2016), bahwa faktor-faktor yang berpengaruh terhadap risiko karies pada anak adalah pengalaman karies, banyaknya plak, pH saliva, perilaku ibu dalam pemanfaatan pelayanan kesehatan gigi anak, perilaku ibu dalam pemilihan makanan anak, dan pelaksanaan UKGS oleh guru. ${ }^{12}$ Oleh karena itu pihak sekolah harus memiliki program UKGS agar dapat meningkatkan kesehatan gigi dan mulut siswa sehingga dapat meningkatkan kualitas hidup.

Program UKGS juga dapat berupa pelatihan bagi kader kesehatan gigi dan mulut di sekolah, yang memerlukan komitmen kuat dan dukungan dari kepala sekolah, guru dan orang tua murid. Penyediaan fasilitas Usaha Kesehatan Gigi Sekolah selanjutnya perlu diikuti dengan upaya pembinaan agar terus berlangsung secara kontinyu agar target WHO di masa mendatang adalah tingkat DMF-T pada anak-anak usia 12 tahun mencapai nilai dibawah $3 .{ }^{11}$ Faktor resiko karies berbeda antar individu, sehingga beberapa metode seperti pendekatan kariogram untuk mengetahui faktor-faktor yang berhubungan dengan karies telah dilakukan oleh beberapa peneliti.

Hasil penelitian oleh Wardani R, dkk, (2017), menyebutkan bahwa karies dapat dicegah melalui pengaturan pola makan, program pencegahan, misalnya penggunaan fluoride, kontrol bakteri serta memperbaiki kualitas sekresi saliva yang didapatkan menggunakan analisis kariogram. ${ }^{13}$ Lebih lanjut jika kondisi gigi dan mulut tidak terjaga dengan baik dapat 
menyebabkan masalah yang lain di sekitar mulut, diantaranya gigi yang berlubang menimbulkan sakit yang mengganggu aktifitas, penumpukan karang gigi dan plak gigi, peradangan dan infeksi pada gusi, sariawan, dan kelainan-kelainan yang lain di sekitar gigi yang akan menyebabkan penurunan kualitas hidup individu. ${ }^{14,15}$

Sebagai bahan pertimbangan lain bagi pihak sekolah, dapat diinformasikan bahwa kesehatan gigi dan mulut dipengaruhi oleh empat faktor penting yaitu keturunan, lingkungan (fisik, biologi, sosial), perilaku dan pelayanan kesehatan. Faktor perilaku memegang peranan penting dalam mempengaruhi status kesehatan gigi dan mulut, sedangkan perilaku dipengaruhi oleh pendidikan. Pendidikan tidak hanya didapat secara formal di sekolah tapi juga di rumah dengan bimbingan orangtua. ${ }^{15}$ Pihak sekolah dapat memberikan penyuluhan dengan bantuan pihak tenaga kesehatan gigi jika diperlukan untuk meningkatkan kualitas kesehatan terutama dalam bidang gigi dan mulut bagi siswa sekolah dasar.

\section{SIMPULAN}

Karakteristik karies gigi permanen berbeda dengan karies gigi sulung pada periode gigi campuran anak usia 6-7 tahun. Prevalensi karies ditemukan sebesar $94,23 \%$, permukaan gigi permanen yang paling banyak mengalami karies adalah permukaan oklusal, sedangkan pada gigi sulung adalah permukaan mesial dan distal (proksimal). Kedalaman karies gigi permanen sebagian besar masih dalam keadaan superfisial, sedangkan pada gigi sulung adalah karies profunda. Indeks def-t gigi sulung menunjukkan nilai sangat tinggi $(8,67)$, namun kerusakan gigi permanen berdasarkan indeks DMF-T menunjukkan hasil yang sangat rendah $(0,4)$.

\section{DAFTAR PUSTAKA}

1. Badan Penelitian dan Pengembangan Kesehatan. Riset kesehatan dasar. Kementerian Kesehatan Republik Indonesia 2013. h. 118.

2. Departemen kesehatan RI. Profil Kesehatan Profinsi Jawa Barat; 2017.

3. Kementerian Kesehatan Republik Indonesia. Pedoman Usaha Kesehatan Gigi Sekolah; 2012.
4. Hiremath S. Textbook of preventive and community dentistry. India: Reed Elsevier (India private printed). 2011. h. 300, 211-5.

5. Ngo H, Gaffney S. Risk assessment in the diagnosis and management of caries. In: Mount GJ, Hume WR, eds. Preservation and restoration of tooth structure. Queensland: Knowledge. 2007. h. 61-82.

6. Amirabadi F, Bazrafshan E, Dehghan J, Zazouli MA. Evaluation of decayed, missing and filled teeth (DMFT) index in the 8-12 years old students of zahedan city, Iran. IJHS 2015;3(2):52-60.

7. Silvia, Cypriano S. Dental caries experience in 12-year-old schoolchildren in southeastern Brazil. J Appl Oral Sci 2008;16(4):286-92.

8. Fathiah. Gambaran tingginya Angka Karies Gigi pada SD binaan pelayanan Asuhan di Wilayah Kota Pontianak. Jurnal Vokasi kesehatan. 2015;3(1):85-90.

9. Aida F, Nila K. Gambaran tingkat kesehatan gigi anak usia dini berdasarkan indeks def-t pada siswa PAUD kelurahan jati kota padang. Andalas Dental Journal. 2015. h. 29-38.

10. TK Bhagat, A Shresta. Prevalence of dental Caries among public school children in eastern Nepal. J Chitwan Med College. 2014;4(7):30-32.

11. Ahmadzadeh J, Rezaeian S, Esmahili-Sani A, Lava B, Mobaraki K, et al. Oral health status and behaviors of children aged 6-12 years old: A cross-sectional study. Ann Public Health Res. 2015;2(2):10-17.

12. Quroti A, Julita H, Al Supartinah. Pengaruh keadaan rongga mulut, perilaku ibu, dan lingkungan terhadap risiko karies pada anak. Majalah Kedokteran Gigi Indonesia. 2016;2(2):86-94.

13. Wardani R, Zubaedah C, Setiawan AS. Occlusal caries risk assesment using cariogram analysis in student aged 11-12 years. Padjadjaran Journal of Dentistry. 2017;29(1):14-21.

14. Setyaningsih D. Menjaga kesehatan gigi dan mulut. Jakarta: CV. Sinar Cemerlang Abadi Rineka Cipta. 2007. h. 50.

15. Astoeti TE. Efektifitas pengelolaan pendidikan kesehatan gigi dengan pendekatan total quality management pada anak sekolah. Indonesian Journal of Dentistry. 2006;13(3):150-5. 